\title{
Experimental assessment of the thermal performance and energy consumption of a single-family Passive House
}

\author{
I.M. Suárez-Ramón ${ }^{1}$, C. Ruiz ${ }^{2}$, I. Duque ${ }^{3}$, A. Zamora ${ }^{3}$, F.J. Fernández ${ }^{1}$, J. Díaz ${ }^{1}$ \\ ${ }^{1}$ Energy Department - University of Oviedo \\ Edificio Departamental Este, Campus de Gijón, 33204 Gijón (Spain) \\ Phone number: +34 985 182365, e-mail: ines@uniovi.es, javierfernandez@uniovi.es, diazjose@uniovi.es \\ ${ }^{2}$ Camino de Monteviento 1225, 33204 Gijón (Spain) \\ Phone number: +34 985 092730, e.mail: carlos.ruizmanso@gmail.com \\ ${ }^{3}$ Duque y Zamora Arquitectos \\ C/ Doctor Marañón 2A, $7^{\circ} \mathrm{L}, 33402$ Avilés (Spain) \\ Phone number: +34 985 560279, e-mail: duqueyzamora@gmail.com
}

\begin{abstract}
This paper presents an experimental study of the thermal performance of a single-family house located in a coastal city in northern Spain that was certified by the Passive House Institute in 2018. An Internet-of-Things-based home automation system registers temperature and relative humidity in most of the thermal zones of the house, and also main operational variables and energy consumption of the heat recovery ventilation system and the aerothermia heat pump that provides for domestic hot water and space heating. The hourly electrical energy consumptions of the house are additionally available through the intelligent metering system of the electrical supply company. The results indicate a high thermal comfort in the house in terms of room temperature and relative humidity, with a total annual primary energy consumption of $102.5 \mathrm{kWh} / \mathrm{m}^{2}$ on heating installation, domestic hot water and household electricity, that is below the limit of $120 \mathrm{kWh} / \mathrm{m}^{2}$ specified by the Passive House Institute.
\end{abstract}

Key words. Passive house, thermal performance, energy consumption, heat pump, pellets stove.

\section{Introduction}

In recent years, the measures derived from the Energy Efficiency Directive 2012/27/EU [1] to reduce the energy consumed in buildings for domestic hot water production, space heating or cooling, lighting and electrical appliances, have led to an increase of the number of passive buildings constructed in many state members. Among the different concepts of energy-efficient buildings, the Passive House construction Standard [2] have been internationally recognized and the requirements of the standard are used by the European Union as design principles for the construction of nearly zero-energy buildings [3]. The annual energy demand of buildings that meet the standard is maintained below highly-demanding limits due to key aspects, such as the use of passive construction techniques aimed at maximizing solar radiation in winter and shading in summer, the use of good insulation in the envelope elements that minimize thermal bridges, the installation of high-efficiency ventilation systems with heat recovery, and the achievement of high air-tightness of the building.

Initially conceived in Germany in 1988, the Passive House Standard has widely spread worldwide and nowadays is present in regions under severe colder and warmer climates than the German conditions, as this concept can be adapted to any climate zone. Several studies have reported the degree of success of the standard implementation in Romania [4-6], Cyprus [7], UK [8], Belgium [9] and Australia [10]. Most of the authors coincide on the high indoor thermal comfort perceived by the occupants and the low energy consumption, and many of them indicate high dependence of the building performance on occupant's behaviour.

The Passive House Institute building database [11] reports 4811 buildings, mainly concentrated in Germany (2377), Austria (1061), France (332), the United Kingdom (167), Spain (155) and Italy (91). Despite the fifth position of Spain in number of passive buildings constructed under the standard, the authors have not found any published work about their performance under the climate conditions of this country. However, as concluded in some works, there is a need of post-occupancy evaluation research. Pilot projects that provide real-time monitoring on the energy performance and evaluation of user satisfaction, contribute to get knowledge about the operational features of the building, and this information could lead to recommendations for improving quality and comfort, help the users' adaptive behaviour to the building, and also increase the demand of such type of construction $[4,7,12$ 13].

In that sense, this paper contributes to the state-of-the-art on the thermal performance of passive houses by reporting a new case study applied to a single-family house located 
in northern Spain that was built and certified by the Passive House Institute in 2018. The study is based on performance data registered during a period of fifteen months. The primary objectives are to quantify the energy consumption of the house and to evaluate the thermal comfort in order to verify how close from the predictions of the Passive House Planning Package (PHPP) the real performance is. For that purpose, temperature and relative humidity were measured in many rooms of the house, as well as main operational variables and energy consumption of the heat recovery ventilation system and the aerothermia heat pump that provides for Domestic Hot Water (DHW) and space heating, that allow calculating the seasonal efficiency of both equipment. In addition, the hourly electrical energy consumptions of the house registered by the intelligent metering system of the electrical supply company were analysed.

\section{Description of the building}

The building is a single-family house occupied by a medium family of five people that lives in the house throughout the year. The house is located in Gijón, a coastal city in northern Spain (latitude $43^{\circ} 32^{\prime} \mathrm{N}$, longitude $5^{\circ} 37^{\prime} \mathrm{W}$ ). The weather is basically oceanic, with moderate average temperatures (around $9.5^{\circ} \mathrm{C}$ in winter and $19.5^{\circ} \mathrm{C}$ in summer), abundant rainfall during the cold season and intermittent winds. The house was built and certified under the Passive House Standard in 2018, and consists of a usable area of $232 \mathrm{~m}^{2}$ divided in three floors. Fig. 1 shows a South-West view of the house and Table I summarizes the layout of the rooms.

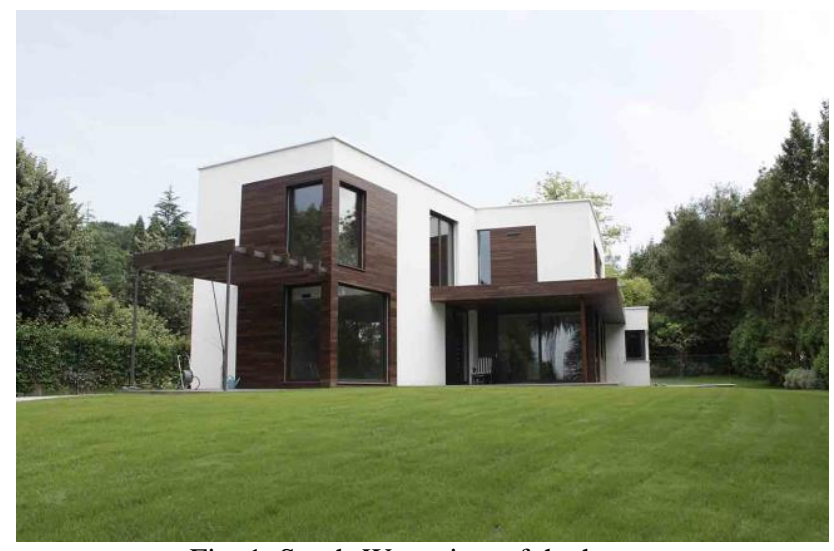

Fig. 1. South-West view of the house

\section{A. Thermal envelope}

The basement slab is made of $300 \mathrm{~mm}$ reinforce concrete, $100 \mathrm{~mm}$ XPS insulation, $60 \mathrm{~mm}$ concrete and $150 \mathrm{~mm}$ stone floor. The underground walls in contact with the soil are made of $60 / 120 \mathrm{~mm}$ XPS insulation, $250 \mathrm{~mm}$ reinforce concrete, $50 \mathrm{~mm}$ thermal insulation and $18 \mathrm{~mm}$ plasterboard. The exterior walls are made of $90 \mathrm{~mm}$ cross laminated timber (Hasslacher Nordica Timber), air stop barrier, 60/120/180 mm EPS insulation (depending on orientation and outer finishing material), and silicone resine plaster or wood as outer finishing materials. The flat roof is composed of 90/120/160 mm cross-laminated timber, air stop barrier, $50 \mathrm{~mm}$ XPS insulation, $80 \mathrm{~mm}$ concrete, waterproofing and $60 \mathrm{~mm}$ gravel. The inner finishing materials in both exterior walls and flat roof are cross- laminated timber or $50 \mathrm{~mm}$ thermal insulation and $18 \mathrm{~mm}$ plasterboard.

Table I. - Room layout of the house

(UF: Underground floor - GF: Ground floor - FF: First Floor T: Temperature - HR: Relative Humidity)

\begin{tabular}{|c|l|c|c|}
\cline { 2 - 4 } \multicolumn{2}{c|}{} & Usable area $\left(\mathrm{m}^{2}\right)$ & Measurement \\
\hline \multirow{4}{*}{ UF } & Leisure room & 29.91 & $\mathrm{~T}$ \\
\cline { 2 - 4 } & Laundry & 16.23 & - \\
\cline { 2 - 4 } & Storage & 13.67 & - \\
\cline { 2 - 4 } & Stairs & 3.88 & - \\
\hline \multirow{5}{*}{ GF } & Living room & 40.12 & T and HR \\
\cline { 2 - 4 } & Kitchen & 22.19 & - \\
\cline { 2 - 4 } & Room 1 & 14.29 & $\mathrm{~T}$ \\
\cline { 2 - 4 } & Bathroom 1 & 5.28 & - \\
\cline { 2 - 4 } & Hall + stairs & 22.91 & $\mathrm{~T}$ \\
\hline \multirow{5}{*}{ FF } & Room 2 & 20.96 & - \\
\cline { 2 - 4 } & Bathrrom 2 & 6.31 & - \\
\cline { 2 - 4 } & Room 3 & 13.82 & T \\
\cline { 2 - 4 } & Room 4 & 14.06 & - \\
\cline { 2 - 4 } & Bathroom 3 & 4.91 & - \\
\cline { 2 - 4 } & Hall + stairs & 9.11 & \\
\hline
\end{tabular}

Regarding the openings of the house, there is a door located in the North façade and there are 24 windows distributed over the four façades. The entrance door is opaque, made of wood, and incorporates thermal insulation in the cameras, its dimensions being $1.80 \mathrm{~m} \times$ $2.10 \mathrm{~m}$. The windows have wooden-aluminium frame and high performance argon filled (a) and low emissivity (le) 4/18a/4le/18a/4le Guardian ClimaGuard glazing system.

The area weighted average U-value and other performance parameters of the thermal envelope elements are detailed in Table II. The area and orientation of the windows are listed in Table III, showing large window areas in South ( $61 \%$ of the total window area) and West $(24.8 \%$ ) façades for maximizing the use of solar energy, but only necessary and small windows in East $(5.7 \%)$ and North (8.5\%) façades for minimizing the energy losses.

Table II. - Main performance parameters of the thermal envelope elements

\begin{tabular}{|l|c|c|}
\cline { 2 - 3 } \multicolumn{1}{c|}{} & $\begin{array}{c}\text { Area weighted average } \\
\text { U-value }\left(\mathrm{W} / \mathrm{m}^{2} \mathrm{~K}\right)\end{array}$ & $\begin{array}{c}\text { g-value } \\
(\%)\end{array}$ \\
\hline Exterior walls & 0.211 & - \\
\hline Roof & 0.188 & - \\
\hline Basement slab & 0.456 & - \\
\hline Window frame & 0.9 & - \\
\hline Glazing & 0.5 & 53 \\
\hline Entrance door & 0.49 & - \\
\hline
\end{tabular}

\section{B. Heat recovery ventilation system}

The heat recovery ventilation system is a key component in a Passive House that provides fresh filtered air and extracts wet and polluted air without significant heat requirements. In Spain, heat recovery ventilation systems are rare in residential houses.

The core of the system is a high-efficiency heat exchanger. During the heating season, the equipment transfers the 
heat from the extracted air to the supplied air, retaining it into the house and thus reducing the energy required to maintain comfort indoor temperatures.

A Zehnder Comfoair Q350 unit rated at $92 \%$ efficiency is installed in the house, equipped with a post-heating water battery for additional heating under cold outdoor conditions.

Table III. - Area and orientation of the windows (UF: Underground floor - GF: Ground floor - FF: First Floor)

\begin{tabular}{|c|c|c|c|}
\hline & \multirow{3}{*}{$\frac{\text { Area }\left(\mathrm{m}^{2}\right)}{6.346}$} & \multirow{3}{*}{$\begin{array}{c}\text { Orientation } \\
\text { South }\end{array}$} \\
\hline & & & \\
\hline \multirow{3}{*}{ UF } & Leisure room & & \\
\hline & Laundry & 2.951 & South \\
\hline & Storage & 1.599 & West \\
\hline \multirow{10}{*}{ GF } & \multirow{3}{*}{ Living room } & 17.016 & South \\
\hline & & 7.145 & West \\
\hline & & 2.112 & North \\
\hline & \multirow{2}{*}{ Kitchen } & 8.407 & South \\
\hline & & 9.561 & West \\
\hline & \multirow{2}{*}{ Room 1} & 3.516 & South \\
\hline & & 1.284 & West \\
\hline & Bathroom 1 & 1.446 & South \\
\hline & \multirow{2}{*}{ Hall } & 2.701 & East \\
\hline & & 1.879 & North \\
\hline \multirow{7}{*}{$\mathrm{FF}$} & Room 2 & 6.101 & South \\
\hline & Bathrrom 2 & 1.209 & North \\
\hline & \begin{tabular}{|l|} 
Room 3 \\
\end{tabular} & 3.305 & South \\
\hline & \begin{tabular}{|l|} 
Room 4 \\
\end{tabular} & 3.305 & South \\
\hline & Bathroom 3 & 2.161 & East \\
\hline & \multirow{2}{*}{ Hall } & 1.705 & West \\
\hline & & 2.143 & North \\
\hline
\end{tabular}

\section{DHW and heating installation}

The DHW and heating installation is mainly based on a 4.7 $\mathrm{kW}$ aerothermia air-water reversible heat pump Vaillant aroTHERM VWL 55/2 A. The installation is provided with 3001 tank for DHW, and 401 inertia tank for three different heating systems: water towel radiators in the three bathrooms, $29 \mathrm{~m}^{2}$ of underfloor heating in the leisure room of the underground floor, and the post-heating water battery of the ventilation system.

Additionally, there is a $2.5-8 \mathrm{~kW}$ pellet stove Rika Roco Multiair that helps the heating system during especially cold winter days.

\section{Methodology}

The measurement period covers fifteen months, from October 2018 to December 2019, and it has been divided in two sub periods, due to the availability of data:

- $\quad$ Period 1: From October 2018 to September 2019 (one year).

- $\quad$ Period 2: From October to December 2019 (three months).

During Period 1, the data were manually registered and covered the daily electrical and thermal consumptions of the heat pump, and the monthly pellet consumption of the stove. Also, the hourly electrical energy consumptions of the house were available through the intelligent metering system of the electrical supply company. This period has been used to discuss the final energy consumption of the house, in daily, monthly and annual basis, due to three different uses: DHW, space heating, and household electricity (lighting and appliances). Additionally, the limits of the Passive House Standard regarding the space heating demand and the final energy consumption of the house have been checked.

At the end of September 2019, the house was equipped with an integrated smarthouse system based on the standard platform KNX. From the $1^{\text {st }}$ of October 2019, the monitoring system, based on the OpenHab (Open Home Automation Bus) opensource platform, registers temperature and relative humidity in the zones indicated in Table I, and also monitors and controls the main variables of the heat recovery ventilation system and the heat pump. For this reason, Period 2 has been used to discuss the thermal performance of the house and the two main equipment (heat recuperator and heat pump) through the following variables:

- the temperature and relative humidity in selected zones, covering the three floors, all the orientations and different room usages, during the coldest day of the period.

- the temperature and relative humidity of the two streams of air at the inlet and outlet of the heat recuperator, during the coldest day of the period.

- the efficiency of the heat recuperator, during the coldest day of the period and also during the three months.

- the energy consumption and seasonal performance factor of the heat pump during the three months.

The heat recuperator is a cross-flow heat exchanger that preheats the fresh air from outside before entering the house. The required heat is taken from the polluted air extracted from the house, as shown in Figure 2.

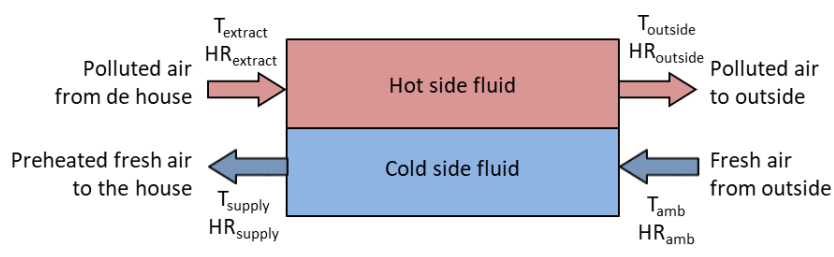

Fig. 2. Heat recovery ventilation heat exchanger

The efficiency of the heat exchanger, $\varepsilon$, is calculated by Eq. (1), that represents the ratio of the heat transfer rate absorbed by the fresh air, and the maximum heat transfer rate that it could absorb if it were heated up to the maximum temperature in the heat exchanger, $T_{\text {extract }}$ :

$\varepsilon=\frac{T_{\text {supply }}-T_{\text {amb }}}{T_{\text {extract }}-T_{\text {outside }}}$

where all the temperatures are in ${ }^{\circ} \mathrm{C}$ and the efficiency can be expressed in \% multiplying by 100 .

The Seasonal Performance Factor (SPF) of the heat pump during a particular period of time, $t$, is obtained through Eq. (2) as the ratio of the thermal energy provided to the 
house, $Q_{\text {thermal }}$, and the electrical energy consumption of the heat pump for DHW, $C_{D H W}$, and space heating, $C_{\text {heating }}$, where energy, thermal and electrical, is in $\mathrm{kWh}$ :

$$
S P F_{t}=\frac{Q_{\text {thermal }}(t)}{C_{D H W}(t)+C_{\text {heating }}(t)}
$$

\section{Results and discussion}

\section{A. PHPP results}

Simulation of the house in the PHPP software is mandatory to obtain the Passive House Institute certification. The software checks the fulfilment of many requirements, as the air tightness, the annual thermal demand and the primary energy consumption, among the most important values.

Air tightness is a key aspect in a Passive House to maintain comfort under low energy consumption. The tightness was tested twice, during and after the construction, using a Blower Door test procedure in accordance with EN 13829:2001, obtaining a measurement of $0.46 \mathrm{~h}^{-1}$ at $50 \mathrm{~Pa}$, value that is below the maximum limit of $0.6 \mathrm{~h}^{-1}$ specified by the Passive House Institute. Additionally, the annual heating demand and primary energy requirement on heating installation, DHW, household electricity and auxiliary electricity calculated according to PHPP, were $5 \mathrm{kWh} / \mathrm{m}^{2}$ year and $29 \mathrm{kWh} / \mathrm{m}^{2}$ year, respectively, both below the maximum limits of the standard.

\section{B. Zone temperature and relative humidity}

The thermal performance of the house has been analysed during the coldest day of Period 2 ( $4^{\text {th }}$ of December 2019), and the most relevant variables are represented in Figure 3.

Firstly, it can be appreciated that despite the low outdoor ambient temperature (it reaches a minimum of $0{ }^{\circ} \mathrm{C}$ at 9:30 $\mathrm{h}$, being the average value along the day $5.4{ }^{\circ} \mathrm{C}$ ) the zone temperatures are maintained between $20^{\circ} \mathrm{C}$ and $21^{\circ} \mathrm{C}$ most of the time.

Additionally, remarkable situations can be observed in the following variables:

- the most stable zone is the leisure room, as it is in the underground and it is not affected by the outdoor ambient conditions.

- the solar radiation highly contributes to increase the temperature in the living room and in the bedrooms (room 1 and 4).

- $\quad$ the peak in the bathroom temperature around 7:15 $\mathrm{h}$ is due to the water towel radiators, that are ON from 7:00 $\mathrm{h}$ to $9: 00 \mathrm{~h}$ when the temperature is below the set point.

- the water post-heating battery that additionally heats up the ventilation air is $\mathrm{ON}$ from 5:00 $\mathrm{h}$ to 10:00 $\mathrm{h}$, when the temperature in the living room is below the set point. This extra heat allows to maintain the zone temperatures almost constant.

- the heat recovery ventilation system reduces the relative humidity in the house around $45 \%$, preventing mould formation and increasing the occupants comfort.

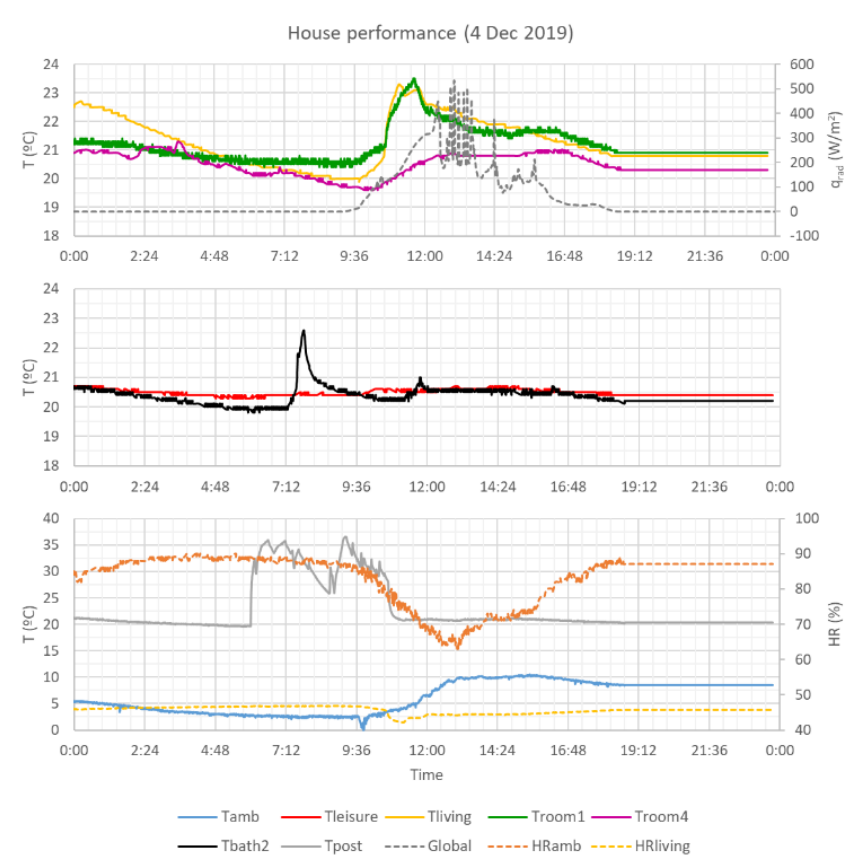

Fig. 3. Zone temperature, zone relative humidity and outdoor ambient conditions during the coldest day of the period Oct-Dec 2019 ( $4^{\text {th }}$ of December)

Finally, Table IV summarizes the maximum, minimum and average zone temperature. It can be observed that the house, even in a very cold day, maintains within the comfort range of temperature.

Table IV. - Maximum, minimum and average temperature outside and inside the house during the coldest day of the period Oct-Dec 2019 (4 $4^{\text {th }}$ of December 2019)

\begin{tabular}{|l|c|c|c|}
\cline { 2 - 4 } \multicolumn{1}{c|}{} & \multicolumn{3}{c|}{ Temperature $\left({ }^{\circ} \mathrm{C}\right)$} \\
\cline { 2 - 4 } \multicolumn{1}{c|}{} & Maximum & Minimum & Average \\
\hline Outdoor ambient & 10.5 & 0 & 5.4 \\
\hline Leisure room & 20.7 & 20.3 & 20.5 \\
\hline Living room & 23.3 & 19.9 & 21.5 \\
\hline Room 1 & 23.5 & 20.4 & 21.2 \\
\hline Room 4 & 21.3 & 19.6 & 20.5 \\
\hline Bathroom 2 & 22.6 & 19.8 & 20.4 \\
\hline
\end{tabular}

\section{Performance of the heat recovery ventilation system and the heat pump}

The performance of the two main thermal equipment of the house (heat recovery ventilation system and aerothermia heat pump), has been analysed during Period 2.

Firstly, the heat recovery ventilation system is analysed during the coldest day of Period 2 in Figures 4 and 5, that show the variation of the air temperature and relative humidity entering and leaving the heat exchanger. It is noticeable the high rise of the temperature of the air supplied into the house. In particular, when the air outside is at $0{ }^{\circ} \mathrm{C}$, the device is able to pre-heat it to $21{ }^{\circ} \mathrm{C}$, absorbing heat from the air that is extracted from the house at $22.8{ }^{\circ} \mathrm{C}$. Regarding the relative humidity, the heat exchanger dries the wet air from outside, thus resulting in highly indoor air quality, as commented before. Figure 4 also represents the variation of the efficiency during the 
coldest day, in which the increment of the efficiency can be appreciated as the temperature gap between the outdoor and the supplied air becomes greater.

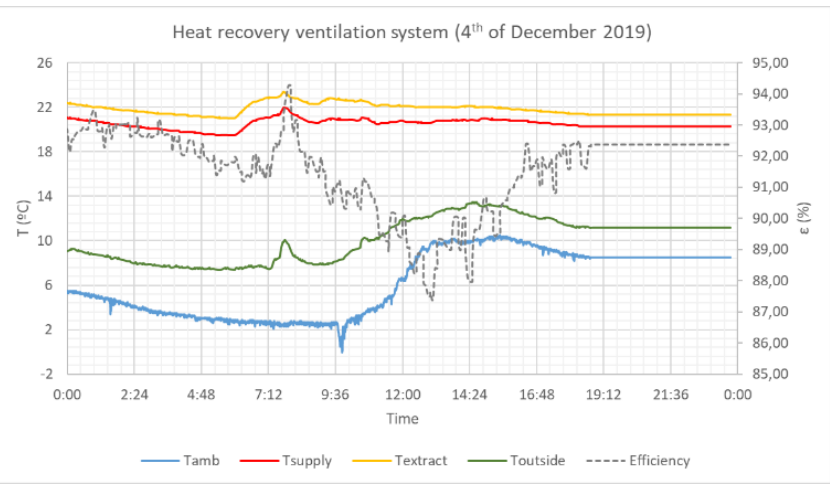

Fig. 4. Air temperature and efficiency in the heat recovery ventilation heat exchanger during the coldest day of the period Oct-Dec 2019 ( $4^{\text {th }}$ of December)

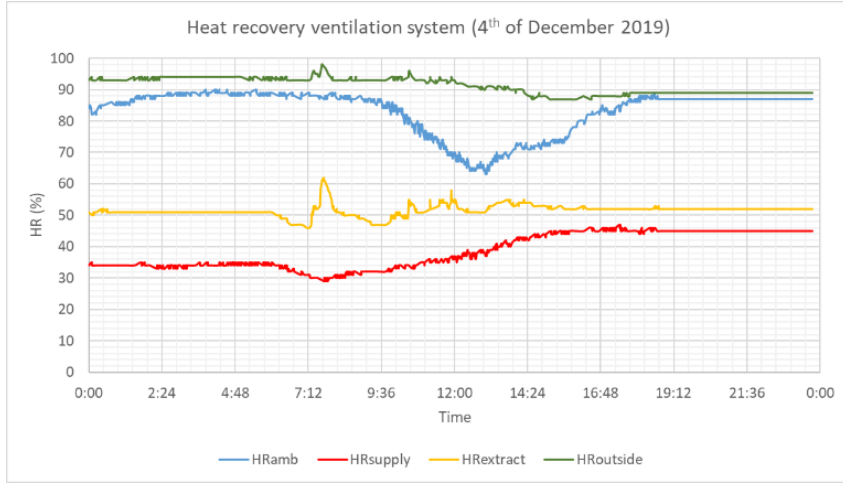

Fig. 5. Air relative humidity in the heat recovery ventilation heat exchanger during the coldest day of the period Oct-Dec 2019 ( $4^{\text {th }}$ of December)

Secondly, the performance of the device along the three months of Period 2 is outlined in Figure 6, where the number of hours operating at efficiency within the range $[80,100] \%$ is represented. This figure allows verifying that the equipment operates most of the time at higher efficiency than the value of $92 \%$ specified by the manufacturer. Deducting the period 8-25 November, when the ventilation system was out of operation due to the exterior air probe failure, the heat exchanger operated $82.4 \%$ of the time of Period 2 with efficiency between $80 \%$ and $100 \%$, being the average value $92.8 \%$.

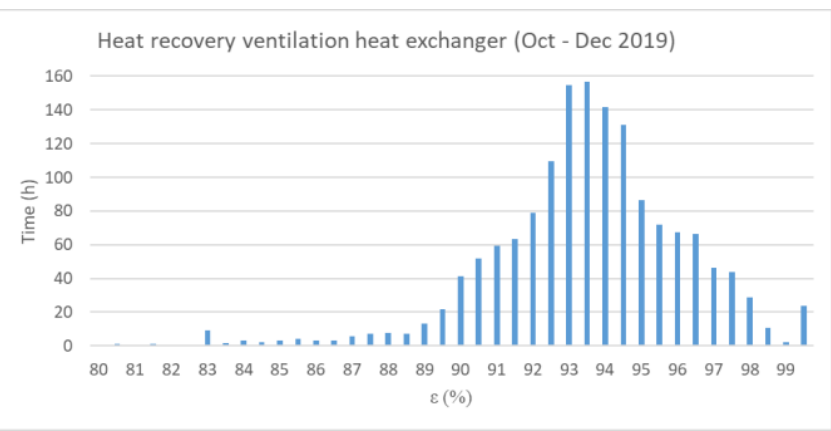

Fig. 6. Efficiency vs. hours of operation of the heat recovery ventilation heat exchanger during the period Oct-Dec 2019
Finally, regarding the heat pump, the thermal energy provided for DHW and space heating, the electrical energy consumption and the PF, all of them in daily basis, are shown in Figure 7. It can be observed that the energy requirements for space heating increase along the three months, while the corresponding to DHW maintain quite constant. Regarding the efficiency of the device, although the manufacturer's catalogue gives a high nominal Coefficient Of Performance (COP) value of 4, the daily SPF calculated from the measured thermal and electrical energy ranges from 1.6 to 3 , being the three-months value equal to 2.1. The reason of these differences is that the SPF is highly dependent on the DHW storage temperature and on the heating system operational temperature, set out at $50{ }^{\circ} \mathrm{C}$ and $45^{\circ} \mathrm{C}$, respectively. If the set points were lower, the SPF would be higher. Unfortunately, in this case it is not possible to set lower values, as it will result in occupants' discomfort.

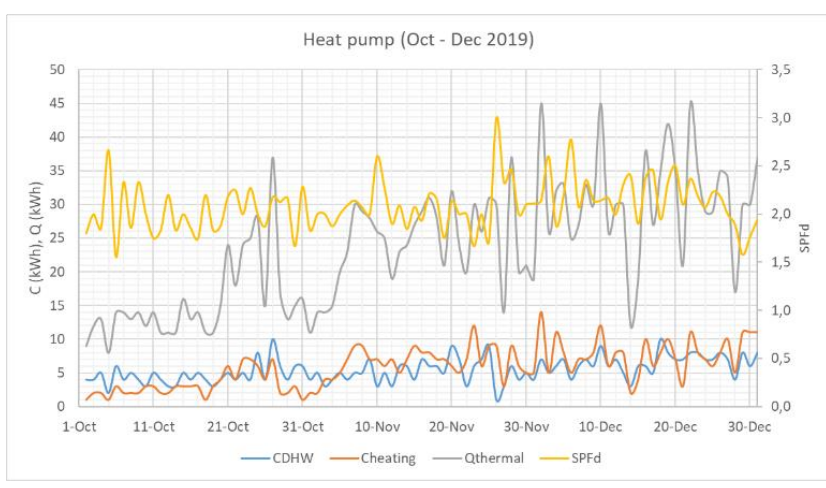

Fig. 7. Daily thermal energy provision, electrical energy consumption and seasonal performance factor of the heat pump during the period Oct-Dec 2019

\section{Final energy consumption}

Period 1 has been used to evaluate the annual energy consumption of the house. Figure 8 shows the evolution of the total daily electrical energy consumption of the house along Period 1. It can be seen that the cold season began around $28^{\text {th }}$ of October, reaching a peak of $48.5 \mathrm{kWh} /$ day. The average electrical consumptions during the warm cold season (November 2018-April 2019) season (MaySeptember), and along the year are 20.7, 31.3 and 26 $\mathrm{kWh} /$ day, respectively.

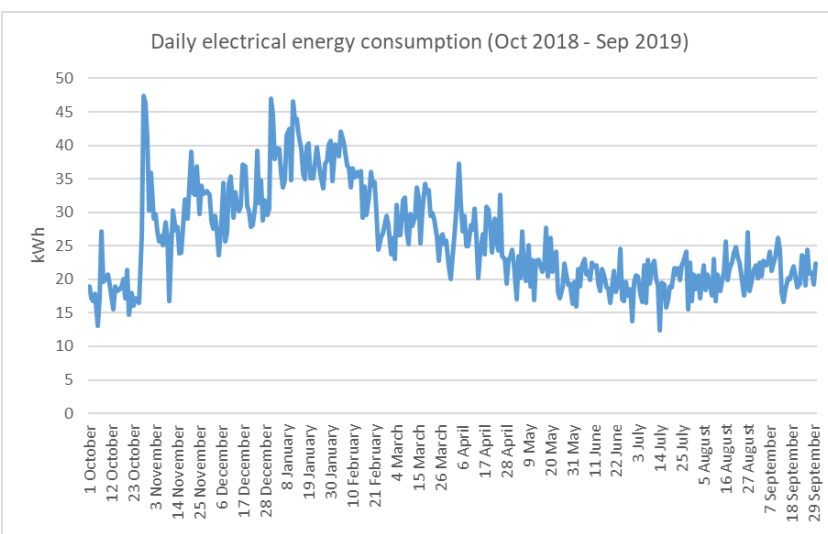

Fig. 8. Daily electrical energy consumption 
Figure 9 shows the total monthly electrical consumption of the house by use. It can be appreciated that the household electricity is quite constant along the year and represents between $45.5 \%$ (in January) to $80.8 \%$ (in August) of the total consumption of the house.

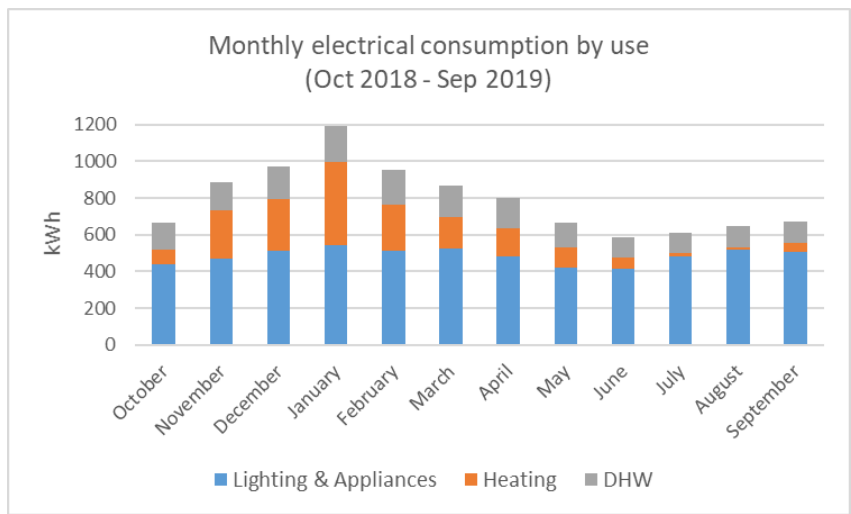

Fig. 9. Monthly electrical energy consumption by use

Figure 10 shows the share of the annual electrical consumption by use. It can be seen that more than half of the total electrical consumption is due to lighting and appliances, and the rest is quite balanced between DHW and space heating.

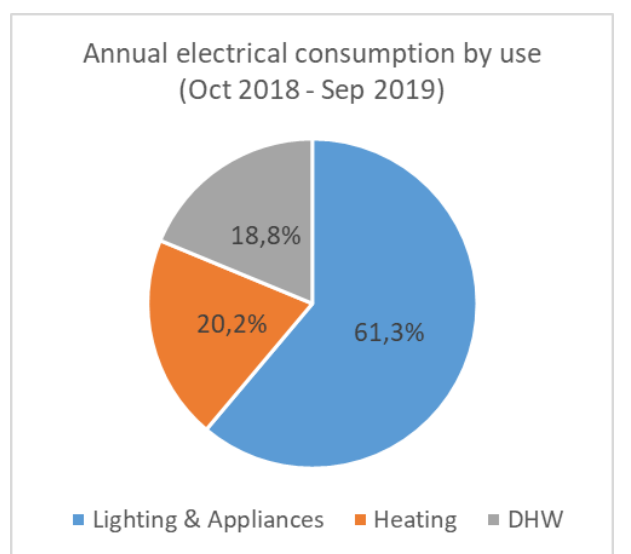

Fig. 10. Annual electrical energy consumption by use

Additionally to the consumption of electricity, $241 \mathrm{~kg}$ of pellets are consumed from November to February, equivalent to $884 \mathrm{kWh}_{\mathrm{PCI}}$.

\section{E. Assessment of Passive House Standard energy consumption limits}

Table V summarizes the annual consumptions per usable surface of the house in terms of final energy (electricity and pellets) and primary energy, showing that the former is quite above and the latter is below the corresponding limits specified by the Passive House Standard.

Table V. - Parameters limited by the Passive House standard (SHD: Space Heating Demand - FE: Final Energy PE: Primary Energy -PH: Passive House)

\begin{tabular}{|c|c|c|c|c|}
\hline $\mathrm{kWh} / \mathrm{m}^{2}$ year & Electricity & Pellets & Total & PH limit \\
\hline SHD & 16.2 & 3.4 & 19.6 & $\leq 15$ \\
\hline FE & 40.9 & 3.8 & - & - \\
\hline PE & 98.2 & 4.2 & 102.5 & $\leq 120$ \\
\hline
\end{tabular}

\section{Conclusions}

The energy consumption and thermal performance of a Passive House is firstly analysed under northern Spanish climate. The study covers a period of fifteen months and the measurements show a high thermal comfort in terms of indoor temperature and relative humidity. Regarding the space heating demand and the primary energy consumption per treated floor area and year, they are around the maximum limits specified by the Passive House Institute standard, the former quite above and the latter quite below. Finally, these two parameters are 3.5 times greater that the corresponding values calculated in the design stage with the Passive House Planning Package, results that are in accordance with other published works. This gap between the performance of the house under real conditions and the PHPP predicted performance is due, basically, to the dependence of the energy consumption on uncontrolled aspects, as the weather conditions or the occupants' behaviour (comfort set point of temperature, type and use of lighting and appliances, etc.).

\section{References}

[1] European Commission. Directive 2012/27/EU of European Parliament and of the Council of 25 October 2012 on energy efficiency. Official Journal of the European Union L315 (2012) $1-56$.

[2] Standard Passivhaus guide. Nearly zero energy building. Energy Foundation in Madrid Community (2010) (In Spanish).

[3] Buildings Performance Institute Europe (BPIE). Principles for nearly zero-energy buildings. Paving the way for effective implementation of policy requirements (2011).

[4] D. Dan, C. Tanasa, V. Stoian, S. Brata, D. Stoian, T. Nagy Giorgy and S.C. Florut, "Passive house design - An efficient solution for residential buildings in Romania", Energy for Sustainable Development (2016), Vol. 32, pp. 99-109.

[5] I. Udrea, C. Croitoru, I. Nastase, R. Crutescu and V. Badescu, "Thermal comfort in a Romanian Passive House. Preliminary results", Energy Procedia (2016), Vol. 85, pp. 575-583.

[6] M. Mihai, V. Tanasiev, C. Dinca, A. Badea and R. Vidu, "Passive house analysis in terms of energy performance", Energy and Buildings (2017), Vol. 144, pp. 74-86.

[7] P.A. Fokaides, E. Chistoforou, M. Ilis and A. Papadopoulos, "Performance of a Passive House under subtropical climatic conditions", Energy and Buildings (2016), Vol. 133, pp. 14-31.

[8] I. Ridley, A. Clarke, J. Bere, H. Altamirano, S. Lewis, M. Durdev and A. Farr, "The monitored performance of the first new London dewlling certified to the Passive House standard", Enery and Buildings (2013), Vol. 63, pp. 67-78.

[9] I. Rehab, P. Andre, C.A. Silva, G. Massy, J. Hannay and J. Lebrun, "Verification of the energy balance of a passive house by combining measurements and dynamic simulation", Energy Procedia (2015), Vol. 78, pp. 2310-2315.

[10] H. Truong and A.M. Garvie, "Chifley Passive House; A case study in energy efficiency and comfort", Energy Procedia (2017), Vol. 121, pp. 214-221.

[11] Passive House Buildings Database, https://passivehousedatabase.org/, accessed 15 Nov 2019.

[12] J. Zhao and K. Carter, "Perceived comfort and adaptative process of Passivhaus participants", Energy Procedia (2015), Vol. 83, pp. 121-129.

[13] E. Mlecnik, T. Schütze, S.J.T. Jansen, G. de Vries, H.J. Visscher and A. van Hal, "End-user experiences in nearly zeroenergy houses", Energy and Buildings (2012), Vol. 49, pp. 471478 . 